\title{
Laboratory assessment of corrosion inhibitors efficiency at oilfield pipelines of West Siberia region II. Tests in a U-cell
}

\author{
I. S. Sivokon, ${ }^{1}$ D. B. Vershok ${ }^{2}$ and N. N. Andreev ${ }^{2 *}$ \\ ${ }^{1}$ OJSC Transenergostroi, Derbenevskaya nab. 7, bldg. 10, Moscow, \\ 115114 Russian Federation \\ ${ }^{2}$ A. N. Frumkin Institute of Physical Chemistry and Electrochemistry, Russian Academy \\ of Sciences, Leninskii pr. 31, Moscow, 119071 Russian Federation \\ *E-mail: n.andreev@mail.ru
}

\begin{abstract}
This paper is a continuation of a series of publications related to laboratory assessment of the performance of carbon dioxide corrosion inhibitors for oilfield pipelines in the West Siberian region. The test results obtained in U-shaped glass cells are considered. The effects of temperature, carbon dioxide content, test duration, specimen surface condition, presence and volume of a hydrocarbon phase, and inhibitor concentration on the corrosion kinetics and protective properties of a wide range of industrial inhibitors are analyzed. Recommendations are given on specific inhibitor test conditions to be used for assessment of inhibitor suitability for the protection of water pipelines and oil pipelines with low watercut.
\end{abstract}

Key words: corrosion inhibitors, corrosion tests, oilfield pipelines.

Received: November 5, 2012.

doi: $\underline{10.17675 / 2305-6894-2012-1-2-130-145}$

\section{Introduction}

Corrosion inhibitors testing in glass U-shaped cell is a popular test $[1,2]$ that simulates the conditions of internal corrosion development in water lines and oil pipelines with low watercut [3]. However, the range of the operational conditions in these pipelines is quite broad [3]. Simulating all of them in each series of the lab tests increase the work scope many times and makes the inhibitors testing more expensive. In view of this, the purpose of this paper is to develop a methodology for assessment of inhibitor performance in a glass U-cell under the critical conditions in terms of corrosion and pipeline failure rate. The authors set the following objectives:

- to analyze the effect of model conditions on steel corrosion kinetics and efficiency of protection by inhibitors based on tests in a glass U-shaped cell;

- to select the simplest test conditions convenient for inhibitor ranking that would simulate critical operation modes of water lines and oil pipelines with low watercut. 
These tasks were addressed by the example of commercial inhibitors produced in Russia and internationally. References to the commercial names of the inhibitors are omitted since the key purpose of this series of publications is optimization of the test methods on real chemicals rather than choice of inhibitors for specific oilfield pipelines. Instead, the inhibitors are marked with numbers from 1 to 7 . Information about their chemical nature is scarce. Inhibitors No. 3, 4 and 7 are qualified by the manufacturers as imidazolines; No. 5 is attributed to quaternary ammonium bases. No. 1 is a mixture of quaternary ammonium bases and imidazoline derivatives. It is only known about inhibitors No. 2 and 6 that they are amine compounds.

\section{Experimental procedure}

The test method uses measurement of the corrosion rates in steel specimens exposed to a flow of corrosive fluids circulating in a U-shaped glass cell [1-3]. The facility consisted of a glass cell supplied with a jacket connected to a thermostat, a propeller stirrer that ensures circulation of the fluid inside the cell, a hermetic drive, an electric motor, and a rack (Fig. 1).

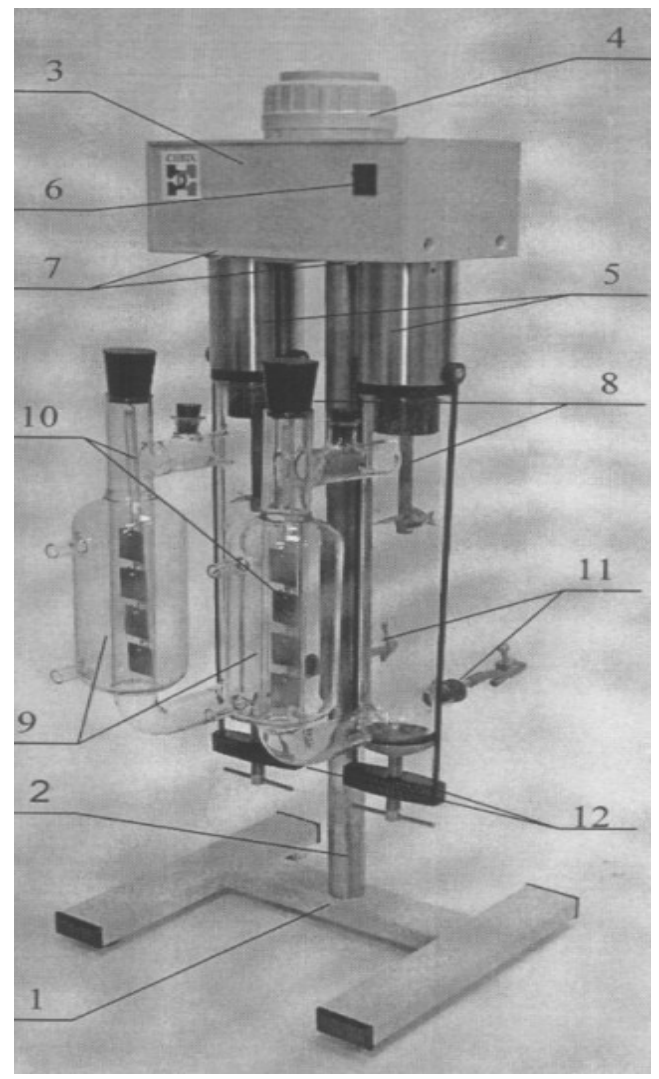

Fig. 1. Facility layout [5]. 1 - rack base; 2 -rod; 3 - case; 4 - electric motor; 5 - hydraulic power drive; 6 - power toggle switch; 7 - fixator; 8 - stirrer; 9 - U-shaped cell with thermostat jacket; 10 - specimen holder with specimens; 11 - choke for fluid/gas admission; 12 - cell mount. 
The aqueous solution simulating the formation water of West Siberia fields /4/ and two-phase model fluids on its basis have been selected as the corrosive fluids.

The aqueous solution simulating the corrosion conditions in water lines was prepared in volumetric flasks filled with water by $85-90 \%$. The following compounds were added, $\mathrm{g} / 1$ with respect to the final volume: $17.40 \mathrm{NaCl} ; 0.76 \mathrm{MgCl}_{2} \cdot 6 \mathrm{H}_{2} \mathrm{O} ; 2.99 \mathrm{CaCl}_{2} ; 0.08$ $\mathrm{FeCl}_{3} \cdot 6 \mathrm{H}_{2} \mathrm{O} ; 0.33 \mathrm{Na}_{2} \mathrm{CO}_{3}$, while $\mathrm{pH}$ of the solution was adjusted to 6.8-7.2 with concentrated $\mathrm{HCl}$. The inhibitor was added to the solution as required, the volume was adjusted to the mark, and the fluid was stirred.

In simulating the corrosion status at oil pipelines with small watercut, a two-phase fluid was used after the following preparation. White spirit or hexane was added to the above solution containing no inhibitors at a rate of 5 parts (by volume) to 95 parts of the solution and then the inhibitor was added as required. The resulting fluid was stirred for $1 \mathrm{~h}$ to ensure equilibrium distribution of the inhibitor and poured to a sealed container. No more than $2 \mathrm{~h}$ before the corrosion tests, the model fluids were placed in a saturator vessel, deaerated by means of nitrogen or argon bubbling, and saturated with carbon dioxide.

At least three parallel experiments were made in each test fluid. The mass losses normally used $[6,7]$ to define the corrosion rates $(K)$ and the inhibitor protection capacity $(Z)$ for the metals were estimated at least in four specimens for each test.

The specimens were made of steel 20. Their surfaces were treated with sand paper, degreased with acetone, and then dried in the air. After that, the specimens were wrapped in filtering paper, placed into a desiccator with calcinated $\mathrm{CaCl}_{2}$, kept there for $24 \mathrm{~h}$, and weighted to within $0.0001 \mathrm{~g}$ on an analytic balance.

To simulate the active state of pipeline steel, the specimens were immersed for $2 \mathrm{~min}$ into a $5 \% \mathrm{H}_{2} \mathrm{SO}_{4}$ solution and washed a stream of distilled water for 30 seconds. The time that the washed specimens stayed in the air did not exceed 1 min. Blank specimens similar to those used in the tests were applied to estimate the mass loss during acid pickling.

Before the tests, the facility was dismounted in compliance with its operation guidelines [5]. The parts contacting the test fluid were washed with a detergent, then with distilled water, rinsed with alcohol, and dried. After that, the cell was re-installed on the rack, and the specimens prepared for the test were fastened to the holder. The cell was purged for 10 min with a stream of an inert gas to remove oxygen. To keep the required temperature, the jacket of the cell was connected to a thermostat.

The model fluid ( 0.5 liters) prepared for the tests was forced over by an inert gas flow to the test cell. After that, liquid circulation inside the cell and in the jacket was started. The flow rate of the corrosive fluid during the test was $1 \mathrm{mps}$. The test time was measured from the moment the cell was filled with the simulation fluid.

After the tests, the specimens were recovered from the holders and inspected. Further, in order to remove the corrosion products, they were placed into a solution $(880 \mathrm{ml}$ distilled water, $66 \mathrm{ml}$ concentrated $\mathrm{H}_{2} \mathrm{SO}_{4}$ of $1.83 \mathrm{~g} / \mathrm{cm}^{3}$ density, $100 \mathrm{~g}$ citric acid, and $10 \mathrm{~g}$ thiourea) for 10-15 s, washed in tap water and then in distilled water, wiped with filtering paper, and placed for $24 \mathrm{~h}$ into a desiccator with $\mathrm{CaCl}_{2}$. The specimens treated in this way 
were again weighted on the analytic balance. After removal of corrosion products by pickling, the specimen mass losses were estimated using witness specimens similar to the corroded specimens in terms of shape, material and size. Unless otherwise specified in the text, the tests lasted for 24 hours and the $\mathrm{O}_{2}$ content in the model fluids was $1.5-2 \mathrm{mg} / \mathrm{l}$.

\section{Results and discussion}

Effect of temperature, dissolved $\mathrm{O}_{2}$ concentration, specimens activation and test duration on steel corrosion rate $(K)$ in uninhibited model fluids. With temperature $(t)$ increase from 8 to $45^{\circ} \mathrm{C}$, the $K$ value increases (Fig. 2). In the tests simulating the operational conditions of water lines (model aqueous solution), a $t$ growth from 8 to $25^{\circ} \mathrm{C}$ results in a $K$ increase from 1.6 to 7.4 and $11.6 \mathrm{~g} \cdot \mathrm{m}^{-2} \cdot$ day $^{-1}$ for air-oxidized and acidactivated specimens, respectively.

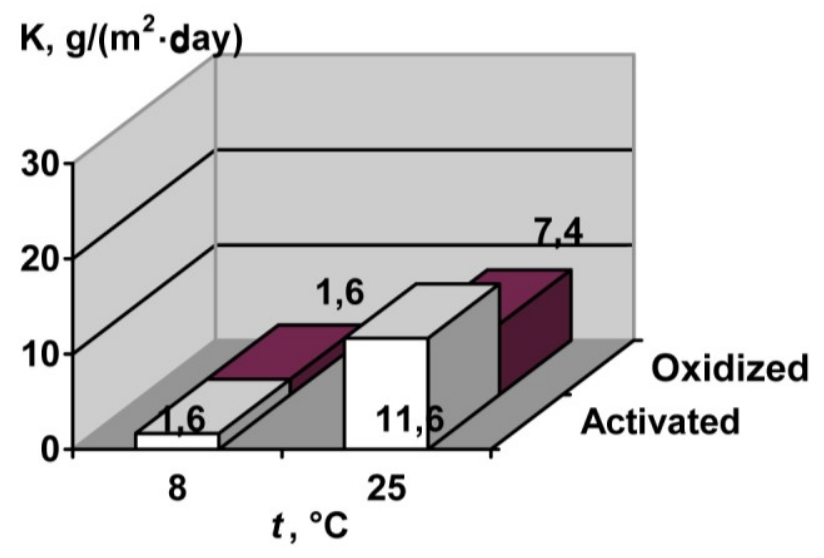

$a$

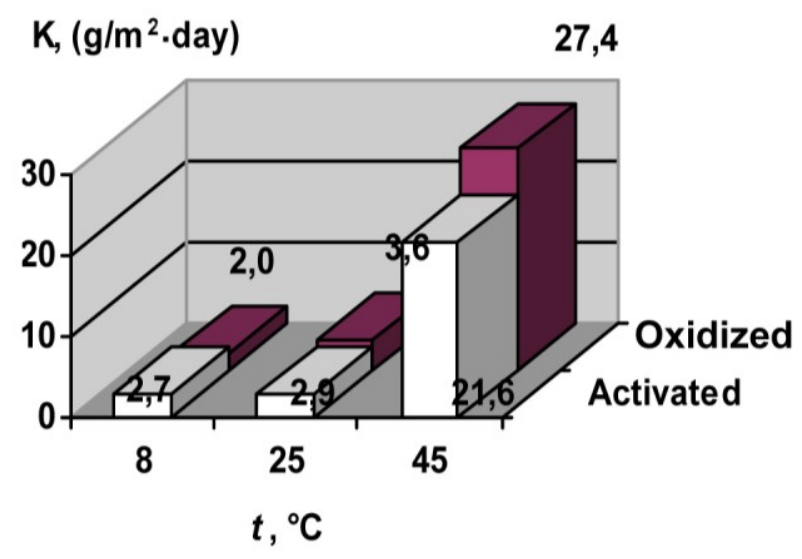

$b$

Fig. 2. Effect of $t$ on $K$ in uninhibited model aqueous solution (a) and two-phase fluid $(b)$.

In simulation of the operational conditions of oil pipelines with low watercut (twophase model fluid containing white spirit), a similar $t$ growth modified the $K$ values to a smaller extent - from 2.0 to 3.6 for air-oxidized steel and from 2.7 to $2.9 \mathrm{~g} \cdot \mathrm{m}^{-2} \cdot \mathrm{day}^{-1}$ for activated steel. Heating of the model fluid by additional $20^{\circ} \mathrm{C}$ strongly intensified corrosion. The corrosion rate increased nearly 7 -fold for both types of specimens.

An increase in $\mathrm{O}_{2}$ concentration in the model aqueous solution from 1.5-2 to 3.5$3.8 \mathrm{mg} / 1$ at $t=25^{\circ} \mathrm{C}$ caused an apparent increase (from 7.4 to $23.2 \mathrm{~g} \cdot \mathrm{m}^{-2} \cdot \mathrm{day}^{-1}$ ) in the $K$ value for air-oxidized steel (Fig. 3). An increase in $\mathrm{O}_{2}$ content to $7.5-6 \mathrm{mg} / \mathrm{l}$ also causes a corrosion rate increase to $27.5 \mathrm{~g} \cdot \mathrm{m}^{-2} \cdot \mathrm{day}^{-1}$.

An increase in the duration of the test in the model aqueous solution from 6 to $24 \mathrm{~h}$ at $t=25^{\circ} \mathrm{C}$ increased the $K$ value for both air-oxidized (from 3.7 to 7.4) and activated specimens (from 7.4 to $11.6 \mathrm{~g} \cdot \mathrm{m}^{-2} \cdot$ day $^{-1}$ ).

Activation of specimens by acid pickling stimulated corrosion in short-term tests. For example, in 6-hour tests at $25^{\circ} \mathrm{C}$, air-oxidized specimens corroded in the model aqueous 
solution at a nearly 2 times smaller rate than activated specimens $\left(3.7 v s .7 .43 \mathrm{~g} \cdot \mathrm{m}^{-2} \cdot \mathrm{day}^{-1}\right)$. If the duration of the tests was increased, these differences related to decomposition of the primary oxide film leveled off. In fact, in 24 hour tests under the same conditions, the $K$ values differed by about $30 \%\left(7.4\right.$ versus $11.6 \mathrm{~g} \cdot \mathrm{m}^{-2} \cdot$ day $\left.^{-1}\right)$.

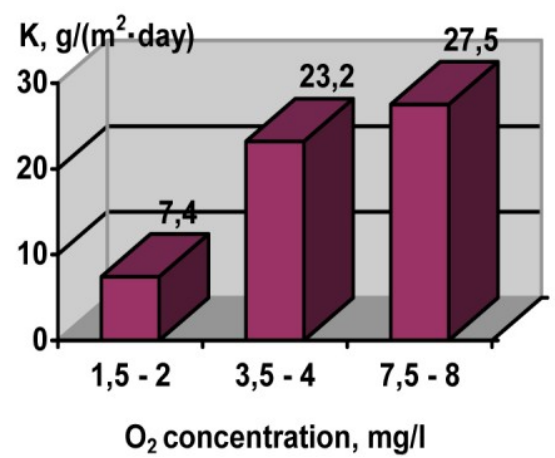

Fig. 3. Effect of oxygen concentration on corrosion rate in air-oxidized specimens at $25^{\circ} \mathrm{C}$ in uninhibited aqueous solution.

In the tests that utilized the model aqueous solution at a lower temperature, $t=8^{\circ} \mathrm{C}$, or in the tests with a two-phase fluid, the differences in the corrosion behavior of differently treated specimens actually did not exceed the data scatter.

The addition of hydrocarbons into the model fluid at the first stage (up to $5 \mathrm{vol} . \%$ ) slowed down the corrosion (Fig. 4). Thus, in 24 hour tests on air-oxidized specimens in aqueous solution at $25^{\circ} \mathrm{C}$, the $K$ value was $7.4 \mathrm{~g} \cdot \mathrm{m}^{-2} \cdot$ day $^{-1}$. In the same fluid containing $5 \%$ hexane, $K=4.0 \mathrm{~g} \cdot \mathrm{m}^{-2} \cdot$ day $^{-1}$, and if hexane is substituted by white spirit, $K=2.5 \mathrm{~g} \cdot \mathrm{m}^{-2} \cdot$ day $^{-1}$. A further growth of the hydrocarbon content in the model fluid increased its corrosivity which achieved a maximum in the fluids containing $30 \%$ of a hydrocarbon phase. If this concentration was exceeded, the $K$ of steel decreased again.

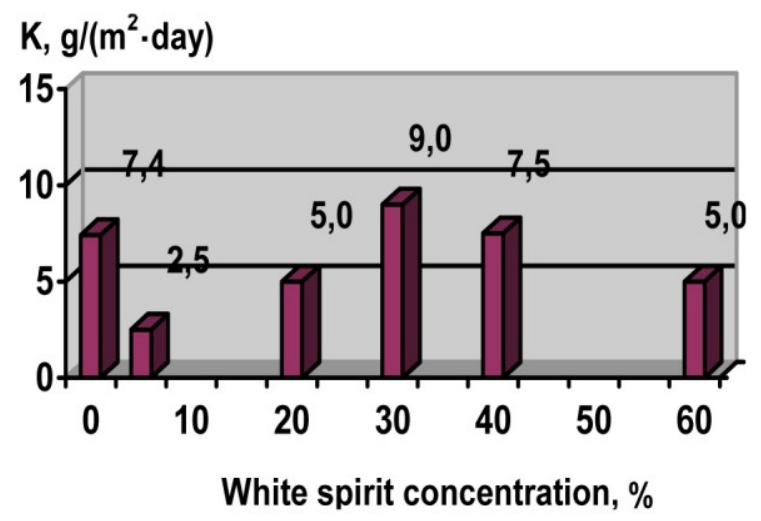

$a$

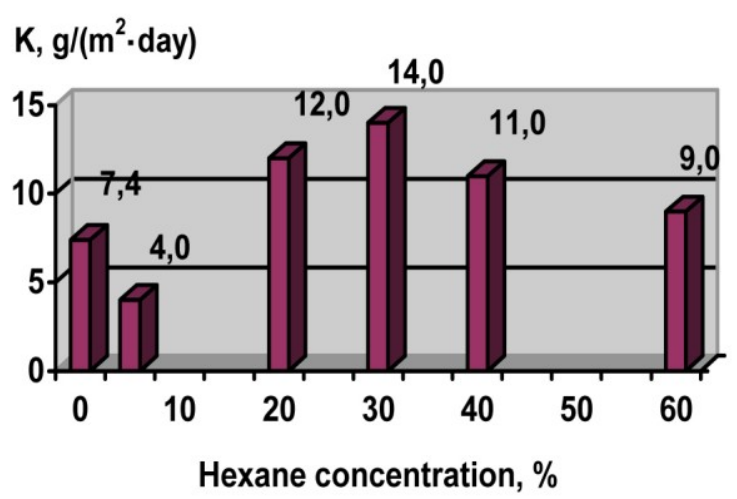

$b$

Fig. 4. Effect of the presence of hydrocarbons on the corrosion rate of air-oxidized specimens at $25^{\circ} \mathrm{C}$ in model fluids. 
The tested inhibitors reduce the $K$ of steel in most cases, though exceptions from this rule were also observed (Table 1). Thus, addition of $50 \mathrm{mg} / 1$ chemical No. 3 into the model fluid stimulated the corrosion of air oxidized specimens at $t=25^{\circ} \mathrm{C}$. Addition of $50 \mathrm{mg} / \mathrm{l}$ of chemical No. 2 slightly accelerated the corrosion of activated specimens under the same conditions.

Table 1. Protective capacity of inhibitors under various test conditions.

\begin{tabular}{|c|c|c|c|c|c|}
\hline Inhibitor No. & Model fluid & $\underset{\mathrm{mg} / \mathrm{l}}{C_{\mathrm{in}},}$ & $t,{ }^{\circ} \mathbf{C}$ & $\begin{array}{c}\text { Specimen } \\
\text { preparation }\end{array}$ & $Z, \%$ \\
\hline 1 & 2 & 3 & 4 & 5 & 6 \\
\hline 1 & Aqueous solution & 10 & 8 & Oxidized & 63 \\
\hline 1 & Same & 25 & 8 & Same & 64 \\
\hline 1 & Same & 50 & 8 & Same & 100 \\
\hline 1 & Same & 50 & 8 & Activated & 64 \\
\hline 1 & Same & 25 & 25 & Oxidized & 27 \\
\hline 1 & Same & 50 & 25 & Same & 73 \\
\hline 1 & Same & 50 & 25 & Activated & 74 \\
\hline 1 & Same & 50 & 8 & Oxidized & 45 \\
\hline 1 & Two-phase fluid & 50 & 8 & Activated & 51 \\
\hline 1 & Same & 25 & 25 & Oxidized & 66 \\
\hline 1 & Same & 50 & 25 & Same & 90 \\
\hline 1 & Same & 50 & 25 & Activated & 71 \\
\hline 1 & Same & 10 & 45 & Oxidized & 88 \\
\hline 1 & Same & 25 & 45 & Same & 95 \\
\hline 1 & Same & 50 & 45 & Same & 97 \\
\hline 1 & Same & 50 & 45 & Activated & 88 \\
\hline 2 & Aqueous solution & 50 & 8 & Oxidized & 75 \\
\hline 2 & Same & 50 & 8 & Activated & 5 \\
\hline 2 & Same & 50 & 25 & Oxidized & 57 \\
\hline 2 & Same & 50 & 25 & Activated & 72 \\
\hline 2 & Two-phase fluid & 50 & 8 & Oxidized & 18 \\
\hline 2 & Same & 50 & 8 & Activated & 34 \\
\hline 2 & Same & 50 & 25 & Oxidized & 38 \\
\hline 2 & Same & 50 & 25 & Activated & $<0$ \\
\hline 2 & Same & 50 & 45 & Oxidized & 53 \\
\hline 2 & Same & 50 & 45 & Activated & 20 \\
\hline 3 & Aqueous solution & 50 & 8 & Oxidized & 80 \\
\hline
\end{tabular}




\begin{tabular}{|c|c|c|c|c|c|}
\hline Inhibitor No. & Model fluid & $\begin{array}{c}C_{\mathrm{in}}, \\
\mathrm{mg} / \mathrm{l}\end{array}$ & $t,{ }^{\circ} \mathrm{C}$ & $\begin{array}{c}\text { Specimen } \\
\text { preparation }\end{array}$ & $Z, \%$ \\
\hline 3 & Same & 50 & 8 & Activated & 50 \\
\hline 3 & Same & 50 & 25 & Oxidized & 47 \\
\hline 3 & Same & 50 & 25 & Activated & 66 \\
\hline 3 & Two-phase fluid & 50 & 8 & Oxidized & 53 \\
\hline 3 & Same & 50 & 8 & Activated & 62 \\
\hline 3 & Same & 50 & 25 & Oxidized & $<0$ \\
\hline 3 & Same & 50 & 25 & Activated & 10 \\
\hline 3 & Same & 50 & 45 & Oxidized & 43 \\
\hline 4 & Aqueous solution & 10 & 8 & Same & 42 \\
\hline 4 & Same & 25 & 8 & Same & 63 \\
\hline 4 & Same & 50 & 8 & Same & 85 \\
\hline 1 & 2 & 3 & 4 & 5 & 6 \\
\hline 4 & Same & 50 & 8 & Activated & 62 \\
\hline 4 & Same & 25 & 25 & Oxidized & 45 \\
\hline 4 & Same & 50 & 25 & Same & 78 \\
\hline 4 & Same & 50 & 25 & Activated & 74 \\
\hline 4 & Two-phase fluid & 50 & 8 & Oxidized & 70 \\
\hline 4 & Same & 50 & 8 & Activated & 43 \\
\hline 4 & Same & 10 & 25 & Oxidized & 66 \\
\hline 4 & Same & 25 & 25 & Same & 85 \\
\hline 4 & Same & 50 & 25 & Same & 79 \\
\hline 4 & Same & 50 & 25 & Activated & 48 \\
\hline 4 & Same & 10 & 45 & Oxidized & 91 \\
\hline 4 & Same & 25 & 45 & Same & 97 \\
\hline 4 & Same & 50 & 45 & Same & 95 \\
\hline 4 & Same & 50 & 45 & Activated & 91 \\
\hline 5 & Aqueous solution & 50 & 8 & Oxidized & 76 \\
\hline 5 & Same & 50 & 8 & Activated & 45 \\
\hline 5 & Same & 25 & 25 & Oxidized & 71 \\
\hline 5 & Same & 50 & 25 & Same & 83 \\
\hline 5 & Same & 25 & 25 & Activated & 73 \\
\hline 5 & Same & 50 & 25 & Same & 81 \\
\hline 5 & Two-phase fluid & 50 & 8 & Oxidized & 45 \\
\hline 5 & Same & 50 & 25 & Same & 85 \\
\hline 5 & Same & 50 & 25 & Activated & 66 \\
\hline
\end{tabular}




\begin{tabular}{|c|c|c|c|c|c|}
\hline Inhibitor No. & Model fluid & $\begin{array}{l}C_{\mathrm{in}}, \\
\mathrm{mg} / \mathrm{l}\end{array}$ & $t,{ }^{\circ} \mathrm{C}$ & $\begin{array}{c}\text { Specimen } \\
\text { preparation }\end{array}$ & $Z, \%$ \\
\hline 5 & Same & 50 & 45 & Oxidized & 91 \\
\hline 5 & Same & 50 & 45 & Activated & 78 \\
\hline 6 & Aqueous solution & 50 & 8 & Oxidized & 53 \\
\hline 6 & Same & 50 & 8 & Activated & 48 \\
\hline 6 & Same & 50 & 25 & Oxidized & 23 \\
\hline 6 & Same & 50 & 25 & Activated & 77 \\
\hline 6 & Two-phase fluid & 50 & 8 & Oxidized & 76 \\
\hline 6 & Same & 50 & 8 & Activated & 50 \\
\hline 6 & Same & 10 & 25 & Oxidized & 65 \\
\hline 6 & Same & 25 & 25 & Same & 74 \\
\hline 6 & Same & 50 & 25 & Same & 89 \\
\hline 6 & Same & 25 & 45 & Same & 83 \\
\hline 6 & Same & 50 & 45 & Same & 88 \\
\hline 6 & Same & 50 & 45 & Activated & 74 \\
\hline 7 & Aqueous solution & 50 & 8 & Oxidized & 65 \\
\hline 7 & Same & 50 & 8 & Activated & 46 \\
\hline 7 & Same & 50 & 25 & Oxidized & 30 \\
\hline 7 & Same & 50 & 25 & Activated & 74 \\
\hline 7 & Two-phase fluid & 50 & 8 & Oxidized & 25 \\
\hline 1 & 2 & 3 & 4 & 5 & 6 \\
\hline 7 & Same & 50 & 8 & Activated & 64 \\
\hline 7 & Same & 50 & 25 & Oxidized & 67 \\
\hline 7 & Same & 50 & 25 & Activated & 53 \\
\hline 7 & Same & 10 & 45 & Oxidized & 73 \\
\hline 7 & Same & 25 & 45 & Same & 97 \\
\hline 7 & Same & 50 & 45 & Same & 99 \\
\hline 7 & Same & 50 & 45 & Activated & 94 \\
\hline
\end{tabular}

Comparison of $Z$ values obtained in the model electrolyte at $t=25^{\circ} \mathrm{C}$ during 24 hour test demonstrates that in most cases, the efficiency of the inhibitors improves along with an increase in their concentration $\left(C_{\text {in }}\right)$ from 10 to $50 \mathrm{mg} / \mathrm{l}$. This is perfectly demonstrated by the example of inhibitors No. 1, 4 and 5 for air-oxidized specimens and No. 5 for activated specimens. Inhibitors No. 2, 3, 6 and 7 are less efficient at $C_{\text {in }}=50 \mathrm{mg} / 1$, so they were not analyzed at $C_{\text {in }}=10$ or $25 \mathrm{mg} / \mathrm{l}$.

The dependencies acquired in the model fluid containing white spirit are more complicated. In case of air-oxidized specimens at $25^{\circ} \mathrm{C}$, the protective effect of inhibitors 
No. 1 and 6 increased with increase in $C_{\text {in }}$ from 25 to $50 \mathrm{mg} / \mathrm{l}$. However, the $Z$ values of inhibitor No. 4 decreased somewhat under these conditions - from $85 \%$ to $79 \%$.

At elevated temperature, $t=45^{\circ} \mathrm{C}$, a parallel growth of $C_{\text {in }}$ and $Z$ was observed for inhibitors No. 1, 6 and 7, whereas the concentration plot of the protective effect for inhibitor 4 passed through an extremum and achieved a maximum value, $Z=97 \%$, at $C_{\text {in }}=$ $25 \mathrm{mg} / 1$.

The effect of $T$ on $Z$ values differs for different model fluids. In aqueous solution, a $t$ growth from 8 to $25^{\circ} \mathrm{C}$ reduced the protective capacity for air-oxidized specimens and increased $Z$ for activated specimens. This is confirmed by the data obtained for all chemicals at $C_{\text {in }}=50 \mathrm{mg} / 1$ (Fig. 5).

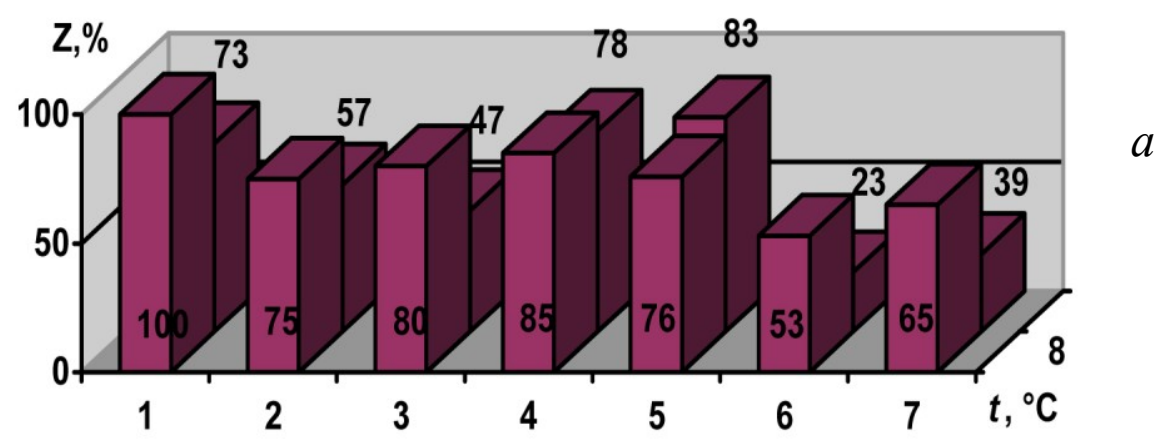

Corrosion Inhibitors

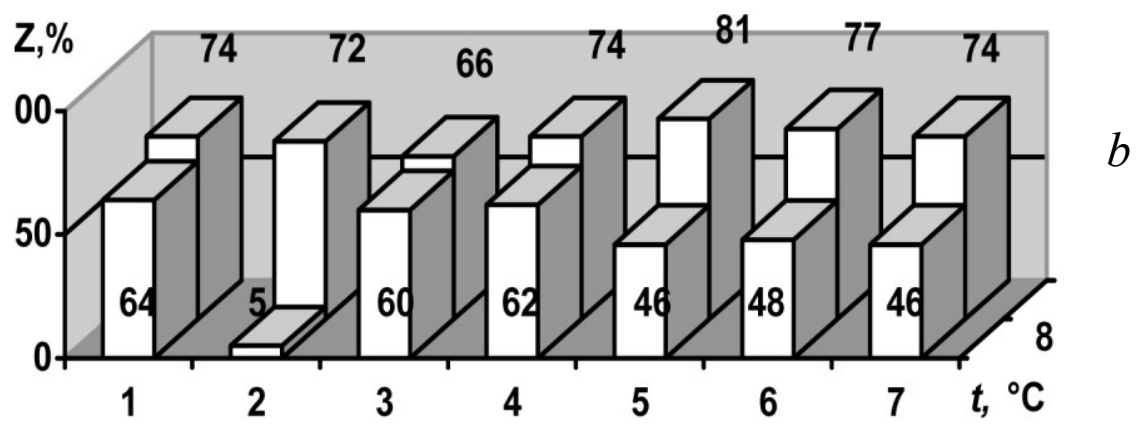

Corrosion Inhibitors

Fig. 5. Effect of temperature on the protective capacity of inhibitors $(50 \mathrm{mg} / \mathrm{l})$ for air-oxidized $(a)$ and activated $(b)$ specimens in model aqueous solution.

In two-phase model fluid, the $Z$ increase was parallel to the $t$ variation for specimens of both types (Fig. 6). Inhibitors No. 3, 2 and 6 make an exception. For chemical No. 3 at $C_{\text {in }}=50 \mathrm{mg} / 1$, transition from 8 to $25^{\circ} \mathrm{C}$ on air-oxidized specimens changed the effect from corrosion inhibition to some stimulation. In case of chemical No. 2, a temperature growth decreased $Z$ of activated specimens, while at $25^{\circ} \mathrm{C}$ corrosion of activated steel was stimulated. In the case of chemical No. 6, heating of the system from 25 to $45^{\circ} \mathrm{C}$ had almost no effect on the protection of air-oxidized steel. 
The effect of oxygen concentration on the protective effect was tested on chemical No. 1 and air-oxidized specimens in model aqueous solution at $t=25^{\circ} \mathrm{C}$ in a 24-hour test (Fig. 7). The protective effect decreased with an increase in $\mathrm{O}_{2}$ content in the model electrolyte. A decrease in $Z$ was also demonstrated for other inhibitors in case of poor sealing of the cell and uncontrolled air access into it.

The effect of test duration on $Z$ was studied at $t=25^{\circ} \mathrm{C}$ in the model aqueous solution on air-oxidized and activated specimens at $C_{\text {in }}=50 \mathrm{mg} / \mathrm{l}$. The results demonstrate that $Z$ increases for all inhibitors in case of the test prolongation from 6 to $24 \mathrm{~h} \mathrm{(Fig.} \mathrm{8),} \mathrm{which} \mathrm{is}$ caused by a quite slow formation of the protective inhibitor film on the steel surface.
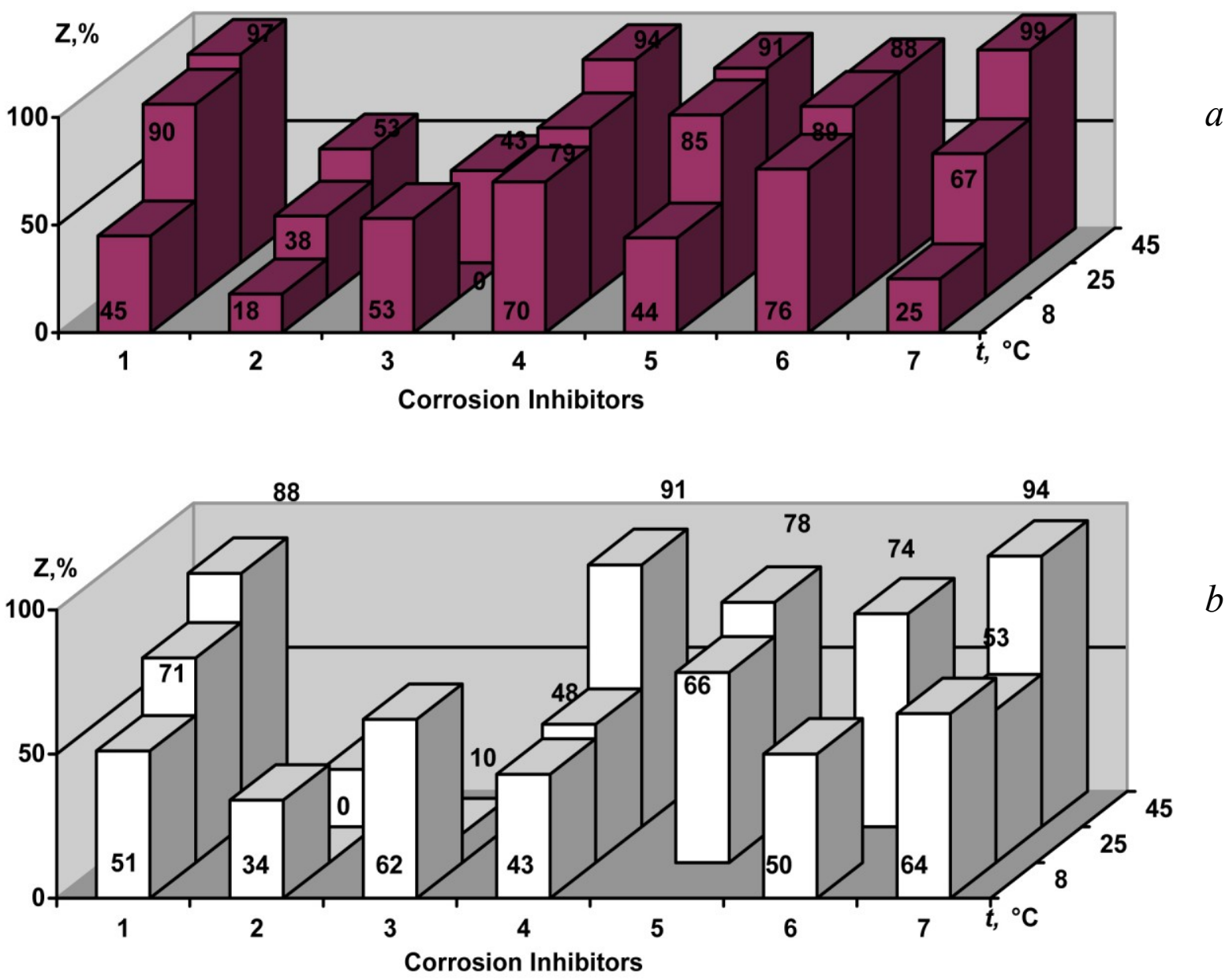

Fig. 6. Effect of temperature on inhibitor protective capacity $(50 \mathrm{mg} / \mathrm{l})$ for air-oxidized $(a)$ and activated $(b)$ specimens in two-phase model environment. 


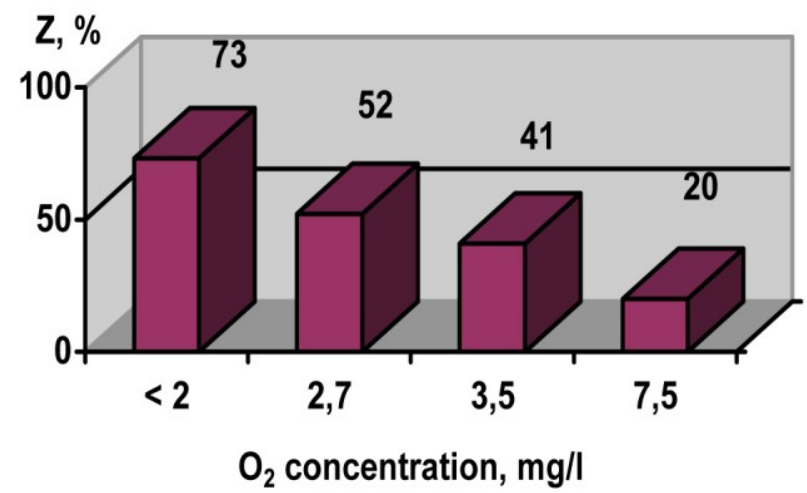

Fig. 7. Effect of oxygen concentration on the protective capacity of inhibitor No. 1 (50 mg/l) for air-oxidized specimens in model aqueous solution at $25^{\circ} \mathrm{C}$.
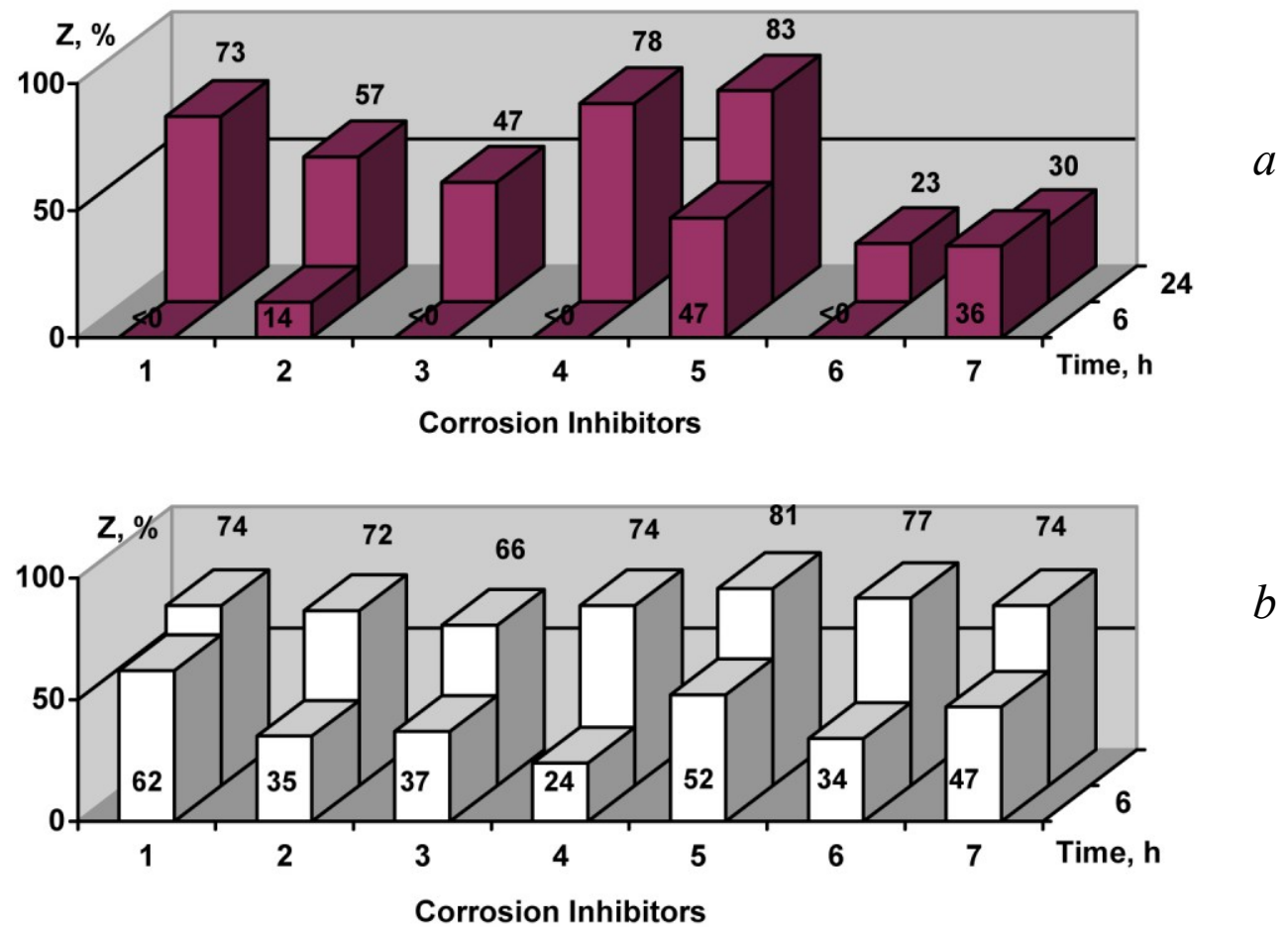

Fig. 8. Effect of test duration on inhibitor protective capacity $(50 \mathrm{mg} / \mathrm{l})$ for air-oxidized (a) and activated $(b)$ specimens in model aqueous solution.

The effect of specimen activation on the protective effect of the inhibitors was tested in the model aqueous solution at $t=25^{\circ} \mathrm{C}$ in 6- (Fig. 9) and 24-hour tests at $\mathrm{O}_{2}$ concentrations of $1.5-2 \mathrm{mg} / 1$. Activation of the specimens either increases or nearly does not affect the protective properties of the inhibitors. The trend of $Z$ increase is observed most clearly in short tests. Adding white spirit (two-phase model fluid) into the system causes a reverse effect, namely, activation of the specimens decreased the $Z$ values.

The effect of the hydrocarbon phase on the protective effect depended on the inhibitor composition (Fig. 10). Comparison of the $Z$ values obtained for the inhibitors in the model electrolyte and in the two-phase model fluid demonstrated that the $Z$ values could increase, 
decrease, or stay the same, depending on the chemical selected and on the specimen preparation. Upon replacement of the model aqueous solution to the two-phase fluid, the $Z$ value increased for oxidized specimens and for chemicals No. 1, 6, and 7. A decrease in $Z$ was observed for chemicals No. 2 and 3. In the case of inhibitors No. 4 and 5, addition of hydrocarbons did not change the protective efficiency. For activated specimens, no $Z$ increase was observed upon addition of white spirit.
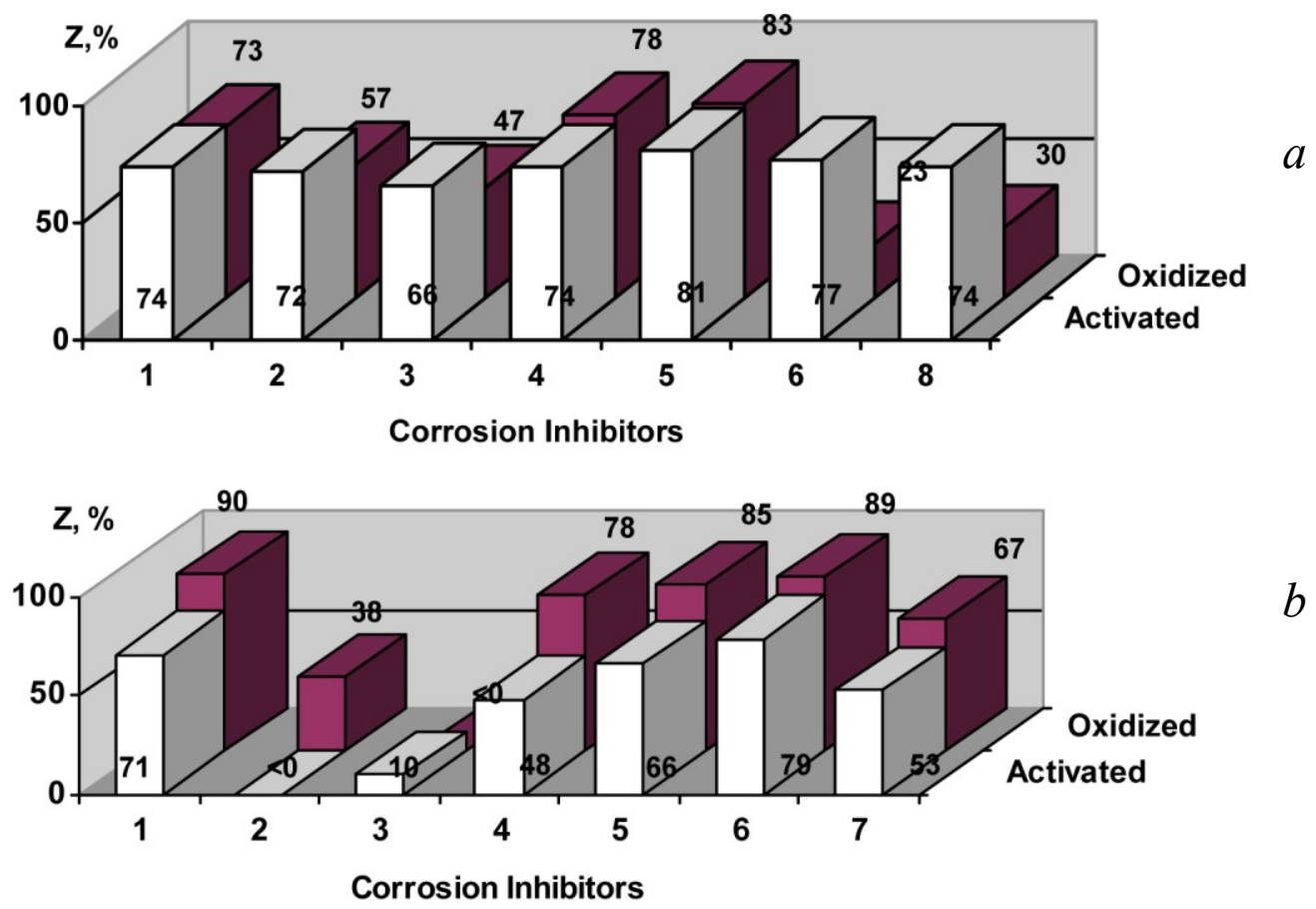

$b$

Fig. 9. Effect of steel activation on the $Z$ of inhibitors $(50 \mathrm{mg} / \mathrm{l})$ in model aqueous solution $(a)$ and two-phase fluid $(b)$. Duration of the tests is 6 hours.

Analysis of the above data exhibits that the key focus in inhibitor ranking should be made on the highest temperature mode in the simulated pipelines. Under these conditions, even the best inhibitors ensure reduction in corrosion rate to the level approaching that in an uninhibited electrolyte at $t=8^{\circ} \mathrm{C}$. Therefore, the protective capacity of the inhibitors at low temperatures is not likely to produce a strong effect on the protection status of simulated pipelines where the failure rate is defined by the operation modes and the sections with elevated temperatures.

In inhibitor ranking, one should also pay attention to the $\mathrm{O}_{2}$ content in the system. As its concentration grows, the corrosion rate increases and the protective effect of the inhibitors declines. The protective capacity of inhibitors at low $\mathrm{O}_{2}$ content would not affect the protection of water lines since their failure rate is defined by enhanced aeration levels. On the other hand, the maximum $\mathrm{O}_{2}$ levels reported in [3] modifies the corrosion 
mechanism. This gives a distorted idea of the efficiency of inhibitors. We believe that the tests should be carried out in electrolytes and model fluids that contain $1.5-2 \mathrm{mg} / 1$ of $\mathrm{O}_{2}$.
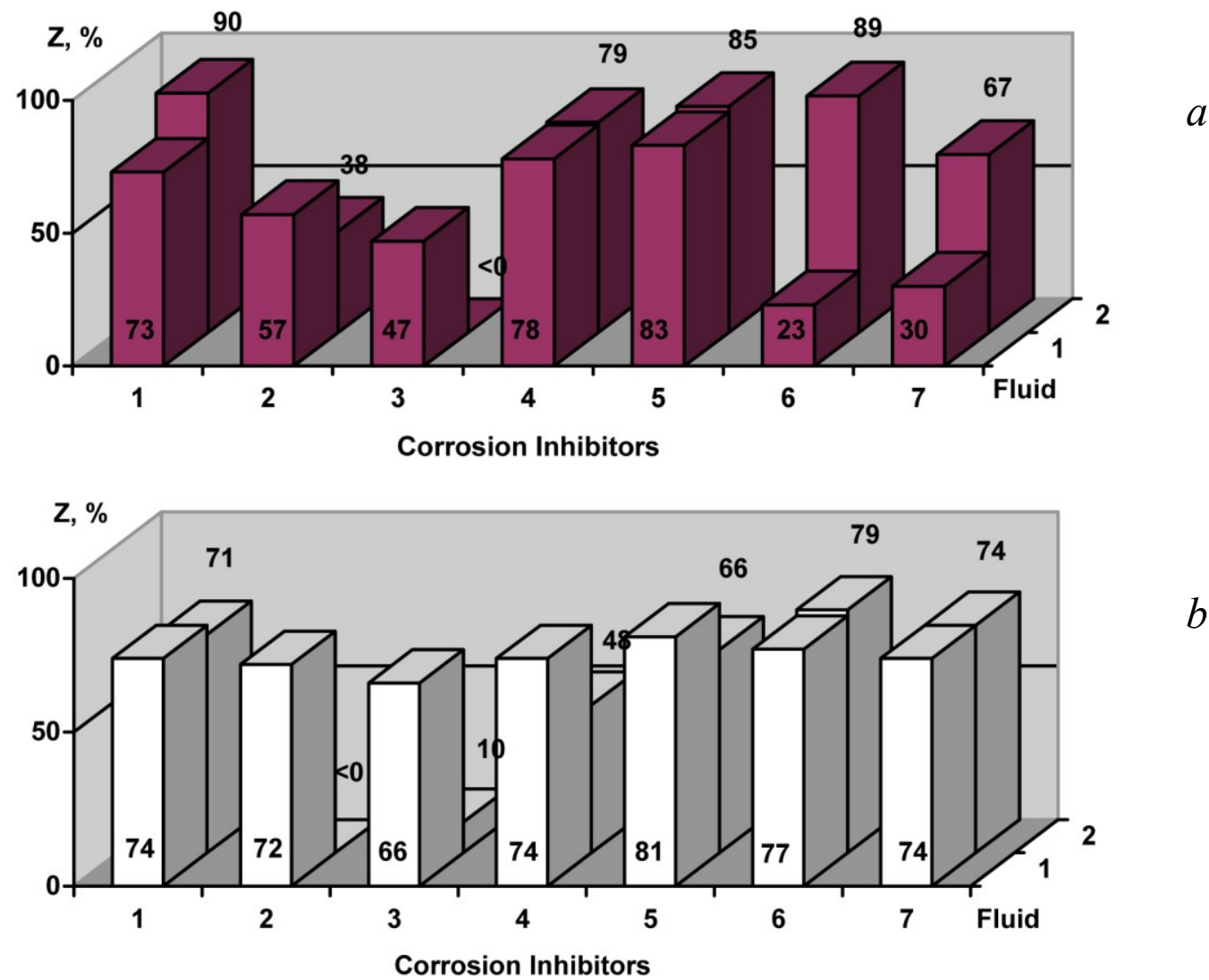

Fig. 10. Protective effect of inhibitors $(50 \mathrm{mg} / \mathrm{l})$ in model aqueous solution (fluid 1$)$ and twophase fluid (fluid 2) at $25^{\circ} \mathrm{C}$ for air-oxidized (a) and activated (b) specimens.

Inhibitor testing in a U-cell should best be performed using 24-hour tests (the maximum continuous operation time of commercially available equipment of this type). The inhibitor film does not have enough time to develop in the recommended 6 hours [1, 2 ] and the results of the test provide an incorrect idea of the protection efficiency.

With this in mind, simulation of water line operation (model aqueous solution) primarily focused on $t=25^{\circ} \mathrm{C}$. Under these conditions at $C_{\text {in }}=50 \mathrm{mg} / \mathrm{l}$, none of the tested inhibitors provided $Z>83 \%$. For air-oxidized specimens, the best three inhibitors in terms of protective capacity form the series:

$$
\text { No. } 5(83 \%)>\text { No. } 4(78 \%)>\text { No. } 1(73 \%) \text {. }
$$

The worst performance for these conditions was demonstrated by inhibitors No. 6 $(23 \%)$ and No. 7 (30\%) (Fig. 11). 

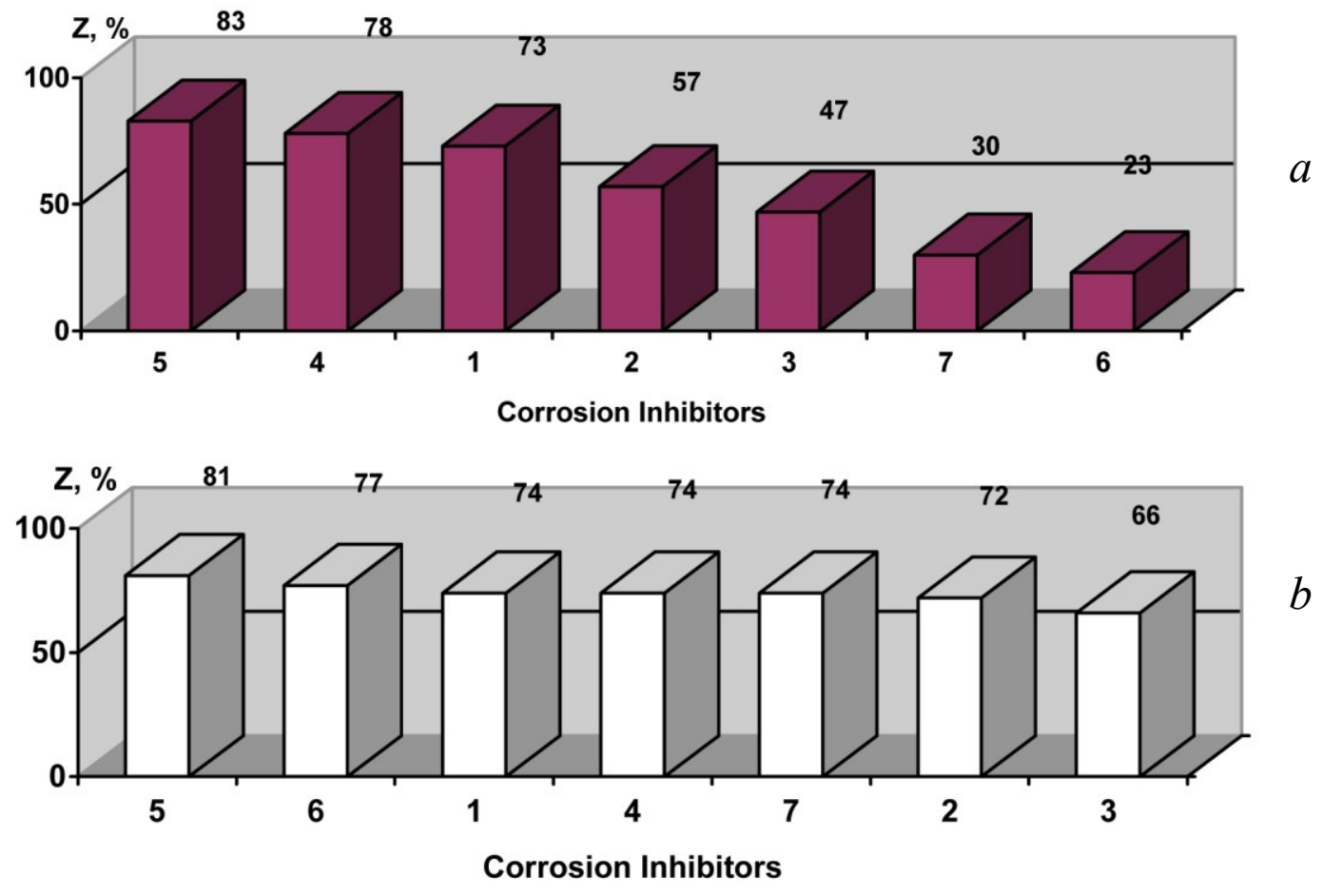

Fig. 11. Protective effects of inhibitors $(50 \mathrm{mg} / \mathrm{l})$ in model aqueous solution at $25^{\circ} \mathrm{C}$ for airoxidized $(a)$ and activated $(b)$ specimens.

For specimens activated by acid pickling, the best performance was demonstrated by inhibitors No. 5 and No. 6. The third position was shared by No. 1, No. 4, and No. 7. Accordingly, the series of best performance was as follows:

$$
\text { No. } 5(81 \%)>\text { No. } 6(77 \%)>\text { No. } 1=\text { No. } 4=\text { No. } 7(74 \%) \text {. }
$$

The worst results were provided by No.3 (66\%).

Inhibitors No. 5, 4 and 1 are common for both "top lists".

In ranking of inhibitors during simulation of oil pipelines with low watercut, the key attention was given to the tests at $t=45^{\circ} \mathrm{C}$. In this case, the "top list" of inhibitors for airoxidized specimens was as follows (Fig. 12):

No. $7(99 \%)>$ No. $1(97 \%)>$ No. $4(95 \%)$.

It is the same as the "top list" for activated steel specimens:

No. $7(94 \%)>$ No. $1(91 \%)>$ No. $4(88 \%)$.

The worst results were delivered by compounds No. 2 and 3 . 

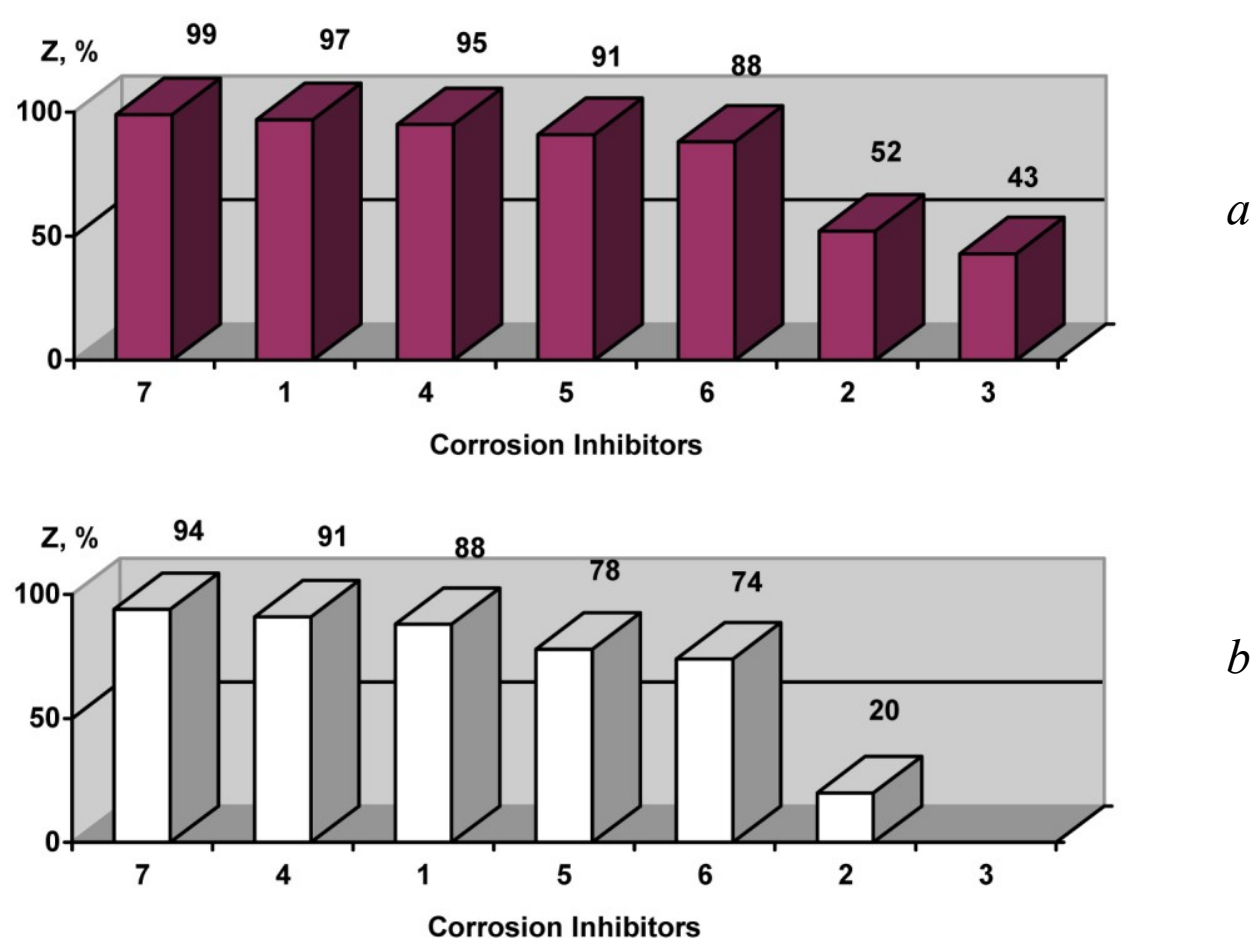

Fig. 12. Protective effects of chemicals $(50 \mathrm{mg} / \mathrm{l})$ in two-phase model fluid at $45^{\circ} \mathrm{C}$ for airoxidized $(a)$ and activated $(b)$ specimens.

\section{Conclusions}

1. During the tests, one should make sure that the tested inhibitor is not hazardous and does not stimulate corrosion at small concentrations.

2. The key focus in the assessment of inhibitor protective properties should be made on the mode with the highest temperatures in the simulated pipelines. The $Z$ values of inhibitors measured at low temperatures does not affect the pipeline protection.

3. The oxygen content in the system should be taken into account when testing inhibitors in a U-shaped glass cell. The tests must be carried out in electrolytes and model fluids that contain $1.5-2 \mathrm{mg} / 1 \mathrm{O}_{2}$.

4. The inhibitor film does not have enough time to develop within the time period recommended by GOST 9.506-87, and the results of the test provide an incorrect estimate of the protection efficiency. The duration of the tests should be 24 hours (the maximum continuous operation time of commercially available equipment of this type).

5. U-cell tests allow us to recommend inhibitors No. 5, 4, and 1 for protection of water lines and inhibitors No.7, 1 and 4 for oil pipelines with low watercut. Inhibitor No.3 is the worst choice for both types of pipelines.

6. The "top lists" for air-oxidized and activated specimens are nearly the same, so the easier treatment of specimens that does not require acid pickling can be used for the tests. 


\section{References}

1. Metodicheskie ukazaniya po ispytaniyu ingibitorov korrozii dlya gazovoi promyshlennosti (Recommended practice for testing of corrosion inhibitors for gas industry), Moscow, RAO GAZPROM (in Russian).

2. GOST (USSR State Standard) 9.506-87, Edinaya sistema zashchity ot korrozii $i$ stareniya. Ingibitory korrozii metallov $v$ vodno-neftyanykh sredakh. Metody opredeleniya zashchitnoi sposobnosti (Unified system of corrosion and ageing protection. Corrosion inhibitors of metals in water-petroleum environments. Methods of protective ability evaluation), Moscow, Standards publishing house, 1988 (in Russian).

3. I. S. Sivokon and N. N. Andreev, Int. J. Corros. Scale Inhib., 2012, 1, no. 1, 65. doi: 10.17675/2305-6894-2012-1-1-065-079

4. V. V.Zav'yalov, Problemy ekspluatatsionnoi nadezhnosti truboprovodov na pozdnei stadii razrabotki mestorozhdenii (Problems of pipelines operational reliability at brownfield stage), Moscow, OJSC VNIIENG, 2005 (in Russian).

5. Ustanovka dlya otsenki zashchitnoi sposobnosti ingibitorov korrozii gravimetricheskim metodom. Pasport i tekhnicheskoe opisanie (SNPKh-GPR-05) (Facility for inhibitors protective ability assessment by gravimetrical method. Specifications and technical description), Kazan, OJSC NIIneftepromkhim, 2010 (in Russian).

6. I. L. Rozenfeld, Ingibitory korrozii (Corrosion Inhibitors), Moscow, Khimiya, 1977 (in Russian).

7. J. I. Bregman, Corrosion Inhibitors, Macmillan, 1963. 